Available online on 15.9.2019 at http://ujpr.org
Universal Journal of Pharmaceutical Research
This is an open access article distributed under the terms of the Creative Commons Attribution-Non
Open access to Pharmaceutical research
Commercial Share Alike 4.0 License which permits unrestricted non commercial use,
provided the original work is properly cited
Volume 4, Issue 4, 2019

\title{
IN-VITRO ANTIBACTERIAL ACTIVITY OF LACTOBACILLI METABOLITES LOADED HYDROGEL FORMULATIONS AGAINST PSEUDOMONAS AERUGINOSA \\ Suna Sibel Gurpınar ${ }^{1}\left(\mathbb{D}\right.$, Burcu Devrim $^{2}\left(\mathbb{D}\right.$, Mujde Eryılmaz $^{1 *}(\mathbb{D}$ \\ ${ }^{I}$ Department of Pharmaceutical Microbiology, Faculty of Pharmacy, Ankara University Ankara, Turkey, ${ }^{2}$ Department of Pharmaceutical Technology, Faculty of Pharmacy, Ankara University Ankara, Turkey.
}

\section{ABSTRACT}

Objective: Pseudomonas aeruginosa is an opportunistic pathogen that may cause serious infections, ranging from localized skin infections to life-threatening systemic diseases. It is one of the resistant bacteria which lead to failure in the treatment. New treatment strategies are urgently needed for the treatment of infections caused by resistant bacteria. Researchers are interested in Lactobacillus species because of their antimicrobial effective metabolites. The aim of this study was comparing the antibacterial activity of lactobacilli metabolites loaded chitosan and Pluronic F127 hydrogel formulations.

Methods: Metabolites loaded hydrogel formulations were prepared by adding $20 \mu \mathrm{l}$ of supernatant into the polymer solutions. The antimicrobial activities of two hydrogel formulations were investigated against $P$. aeruginosa using Agar Spot Method. Metabolites loaded chitosan hydrogel formulations were found to be effective against $P$. aeruginosa.

Results: No antibacterial activity was observed for metabolites loaded Pluronic F127 hydrogel formulations. When we compare these two hydrogel formulations, we observed that hydrogel formulation prepared by using chitosan released effective metabolites but Pluronic F127 hydrogel formulation couldn't release antibacterial effective metabolites.

Conclusion: The antibacterial effect of metabolites loaded chitosan hydrogel formulation suggests that this formulation could be used as an alternative treatment option in P. aeruginosa skin infections. However, further investigations are needed to develop a pharmaceutical product.

Keywords: Antimicrobial activity, bacterial metabolites, chitosan, Lactobacillus sp, Pluronic F127.

Article Info: Received 2 July 2019; Revised 8 August; Accepted 2 September, Available online 15 September 2019

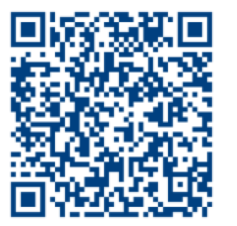

Cite this article-

Gurpınar SS, Devrim B, Eryılmaz M. In-vitro antibacterial activity of lactobacilli metabolites loaded hydrogel formulations against pseudomonas aeruginosa. Universal Journal of Pharm Research 2019; 4(4): 9-11.

DOI: https://doi.org/10.22270/ujpr.v4i4.291

Address for Correspondence:

Dr. Mujde Eryılmaz, Ankara University, Faculty of Pharmacy, Department of Pharmaceutical Microbiology, Ankara, Turkey.E-mail: meryilmaz@ankara.edu.tr

\section{INTRODUCTION}

Antibiotic resistance is a serious public health problem that threatens the all over the world. Day by day, new multi-resistant microorganisms have increasingly been reported from different regions of the world. Failure in the treatment of these resistant bacteria leads scientists to investigate alternative treatment options ${ }^{1,2,3}$. Lactobacillus genus, which is grouped among lactic acid bacteria, comprises of Gram-positive, facultative anaerobic or microaerophilic, non-spore-forming, rodshaped bacteria. These bacteria produce lactic acid as the major metabolic end-product of carbohydrate fermentation. Some groups of them also produce various amounts of compounds such as acetic acid, carbon dioxide, and ethyl alcohol ${ }^{4,5}$. Lactobacilli are the normal flora members of the human body and they commonly found in the mouth, vagina, and intestines ${ }^{6}$. Owing to their metabolites and antagonistic effects, they protect the human body from pathogens ${ }^{7}$. In a healthy premenopausal woman, the dominance of lactobacilli in the vagina is protective against the colonization of pathogenic microorganisms ${ }^{8}$. In recent years, the number of studies reporting the beneficial effects of flora microorganisms on human health has increased. The genus Lactobacillus has taken considerable attention because of their antimicrobial, immune modulatory, anti-inflammatory and anticarcinogenic activities. These microorganisms have been the subject of many investigations to find out whether they can be used as an alternative for the treatment of diseases ${ }^{3,9-12}$. Chitosan, a deacetylated derivative of chitin, is a cationic polymer that consists of a long chain formed by a combination of $\beta-1,4-D-$ glucosamine (deacetylated unit) and N-acetyl-Dglucosamine (acetylated unit) by linking with $\beta(1-4)$ glycosidic bonds. As a natural polymer, it demonstrates 
incredible properties such as biocompatibility, biodegradability, non-toxicity, antimicrobial activity, and adsorption capability. Therefore, it has been extensively studied for its use in many fields. Chitosan is also widely used as a wound dressing due to its excellent hemostatic properties and antimicrobial activities. Its antimicrobial activity has been explained by several theories. The most accepted hypothesis is that its action on bacteria would occur by the loss of its intercellular components. Due to its positive charge, it binds to the bacterial membrane causing a change in permeability and the output of its intercellular components, thus leading to cell death. The antimicrobial activity of chitosan was observed against a wide variety of microorganisms, including fungi, algae, and bacteria, being more active against Grampositive bacteria than Gram-negative ones ${ }^{\text {13-15. }}$.

Poloxamers, poly (ethylene oxide)-poly (propylene oxide)-poly (ethylene oxide) triblock copolymers (PEO-PPO-PEO), are synthetic polymers with thermo reversible behavior in aqueous solutions and widely used in pharmaceutical systems. They are available in different molecular weights with commercial name pluronics. Among pluronics, F127 is widely explored for drug delivery due to its thermo-reversible gelation properties, ability to solubilize hydrophobic solutes and to form micellar structure (incorporate both hydrophilic and hydrophobic drugs) and extending drug release and non-toxicity. Moreover, Pluronic F127 gels have also exhibited improvement in wound healing by stimulating expression of vascular epithelial growth factor and (VEGF) and transforming growth factor (TGF- $\beta 1)^{16,17}$.

The aim of this study was comparing the antibacterial activity of vaginal lactobacilli metabolites loaded chitosan and Pluronic F127 hydrogel formulations against Pseudomonas aeruginosa.

\section{MATERIALS AND METHODS \\ Lactobacillus sp. Isolates}

In this study, metabolites of the seven L. gasseri, two L. crispatus, and one L. helveticus vaginal isolates which were previously identified in terms of specieslevel by analyzing the $16 \mathrm{~S}$ rRNA gene sequence and found effective against some test bacteria were used ${ }^{3}$.

\section{Obtaining metabolites}

Lactobacillus isolates grown on Rogosa Agar for 24-48 hours were inoculated into tubes containing De ManRogosa Sharpe Broth (Merck, Germany), at $37^{\circ} \mathrm{C}$, under anaerobic conditions for 72 hours. After the incubation period, cells were removed by centrifugation $\left(12000 \mathrm{~g}, 10 \mathrm{~min}, 4{ }^{\circ} \mathrm{C}\right)$. The cell-free supernatants were filter-sterilized $(0.45 \mu \mathrm{m}$ pore size $)$ (Minisart, Germany) ${ }^{3,18}$.

\section{Preparation of Chitosan and Pluronic Hydrogels}

Chitosan was dissolved in $1 \%$ acetic acid solution at room temperature with continuous mechanical stirring to obtain a $1 \%(\mathrm{w} / \mathrm{w})$ solution ${ }^{13}$. Metabolite loaded chitosan hydrogel was made by adding $20 \mu \mathrm{l}$ of supernatant into the chitosan solution. Pluronic F127 hydrogel (20 wt $\%$ ) was prepared by gradually adding under magnetic stirring at $4{ }^{\circ} \mathrm{C}$ Pluronic F127 powder to distilled water. The temperature was maintained at
$4^{0} \mathrm{C}$ until complete dissolution of Pluronic F127 powder $^{19}$. Metabolite containing Pluronic F127 hydrogel was prepared by gradually adding $20 \mu \mathrm{l}$ of supernatant into the Pluronic F127 solution under magnetic stirring at $4^{0} \mathrm{C}$.

\section{Antimicrobial activity test}

The antimicrobial activities of the metabolite loaded hydrogel formulations were investigated against Pseudomonas aeruginosa ATCC 27853 using Agar Spot Method $^{20}$. Test bacteria culture grown for 18-24 hours, adjusted to McFarland 0.5, were inoculated onto Mueller-Hinton Agar plate with sterile swabs. $20 \mu \mathrm{l}$ of each of metabolite loaded hydrogel formulations and supernatant were dropped equidistantly onto media inoculated with test bacteria. Lactobacilli supernatants as positive control were used. All the plates were incubated at $37^{\circ} \mathrm{C}$ for $18-24$ hours, under aerobic conditions. After incubation, the growth inhibition in Agar Spot Method was considered as a positive effect.

\section{RESULTS AND DISCUSSION}

Five L. gasseri, one L. crispatus, and L. helveticus metabolites loaded chitosan hydrogel formulations were found to be effective against $P$. aeruginosa. Although chitosan alone had antibacterial activity, it was found that the metabolites loaded chitosan formulations showed better antibacterial activity. Besides that, Pluronic F127 hydrogel formulation didn't provide antimicrobial activity as metabolites couldn't release from hydrogel formulations (Figure 1).

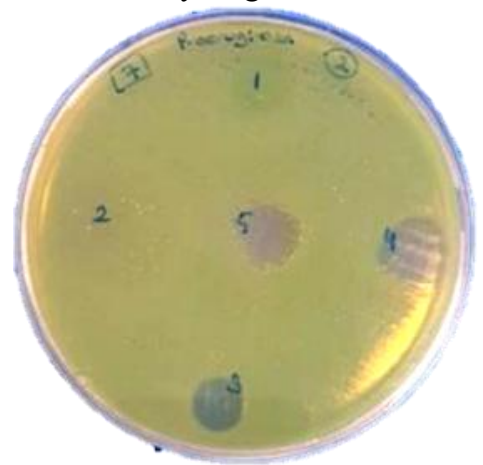

Figure 1: Antimicrobial activity of metabolite loaded hydrogel formulations against Pseudomonas aeruginosa ATCC 27853.

(1: Pluronic F127, 2:Metabolite loadedPluronic F127

hydrogelformulation, 3:Chitosan, 4: Metabolite loaded chitosan hydrogel formulation, $\mathbf{5}$ :Supernatant of vaginal $L$. Gasseri isolate)

This is thought to be due to the high viscosity of the Pluronic F127 hydrogel with a concentration of $20 \%$. When we compare these two hydrogel formulations, we observed that hydrogel formulation prepared by using chitosan released effective metabolites and therefore antimicrobial activity could be observed.Similar results were obtained in the study performed by Boonlai et al., ${ }^{21}$. Among the hydrogels prepared with $16 \%, 18 \%$ and $20 \%$ (w/w) Pluronic F127, the slowest drug release was achieved with the hydrogel formulation prepared with $20 \%$ Pluronic F127. The release results werec onsistent with the microstructural features of the gel matrices. The matrix that possessed the gel barrier with high strength led to slow drug release. In addition, the gel of $20 \%$ Pluronic 
possessed the smallest pore diameter and the highest pore density; therefore, the transportation rate of the drug passing through the gel network was thes lowest. In another study performed by using three P407 hydrogel formulations with concentrations at $16 \%$, $20 \%$ and $24 \%(\mathrm{w} / \mathrm{w})$ also showed that concentration of Pluronic had a significant influence on the release of drug from hydrogel formulation ${ }^{22}$. The concentration of Pluronic was inversely associated with ther elease of drug, i.e., the higher the Pluroniccon centration, the lower the release percentage of drug. This indicates that $\mathrm{P} 407$ retarded the release of drug from formulations. This could be interpreted by viscosity of hydrogel formulations.

\section{CONCLUSION}

In conclusion, the antibacterial effect of vaginal Lactobacillus metabolites loaded chitosan hydrogel formulation suggests that effective metabolite loaded this formulation could be used in the treatment of $P$. aeruginosa skin infections. However, further investigations are needed to develop a pharmaceutical product.

\section{ACKNOWLEDGMENTS}

This study is a continuation of a previously published study. We thank Prof. Dr. Devran Gerceker and Dr. Haluk Guriz for their contributions.

\section{CONFLICT OF INTEREST}

The author(s) confirm that they have no conflict of interest.

\section{AUTHOR'S CONTRIBUTION}

All authors contributed to the study design, data collection, data analysis, data interpretation, and manuscript preparation.

\section{REFERENCES}

1. World Health Organization. Implementation of the global action plan on antimicrobial resistance.www.who.int/ antimicrobial-resistance/news/WHO-GAP-AMR-Newslettermay-2017.pdf?ua=1 (Accessed May 17, 2019)

2. Islam MA, Islam M, Hasan R, Hossain MI, Nabi A, Rahman M, Goessens WHF, Endtz HP, Boehm AB, Faruque SM. Environmental spread of NDM-1-producing multi-drug resistant bacteria in Dhaka, Bangladesh. Appl Environ Microbiol 2017; 83.https://doi.org/10.1128/AEM.00793-17

3. Eryılmaz M, Gürpınar SS, Palabıyık İM, Güriz H, Gerçeker D. Molecular identification and antimicrobial activity of vaginal Lactobacillus sp. Curr Pharm Biotech 2018; 19(15):1241-1247. https://doi.org/10.2174/1389201020666190110164123

4. Huang CH, Li SW, Huang L, Watanabe K. Identification and classification for the Lactobacillus casei group. Front Micr 2018; 9:1974.https://doi.org/10.3389/fmicb.2018.01974

5. Kandler O, Weiss N. Regular Nonsporing Gram-Positive Rods. In: Murray RGE, Brenner DJ, Bryant MP, Holt JG, Krieg NR, Moulder JW, Pfennig N, Sneath PHA, Staley JT. Bergey's Manual of Systematic Bacteriology. $2^{\text {nd }}$ ed. USA: Williams and Wilkins 1986; 1208-1234. https://doi.org/10.4274/tjps.36450

6. Davoodabadi A, Dallal MMS, Lashani E, Ebrahimi MT. Antimicrobial activity of Lactobacillus spp. isolated from fecal flora of healthy breast-fed infants against diarrheagenic Escherichia coli. Jundishapur J Microb 2015; 8:1-6. https://doi.org/10.5812/jjm.27852

7. Kılıç E, Aslım B. Laktik asit bakterilerinin vajen florasındaki önemi ve probiyotik olarak kullanımı. OrLab On-line Mikrobiyoloji Dergisi 2003; 1:70-82.

8. Kovachev S. Defence factors of vaginal lactobacilli. Crit Rev Micr 2017; 8:1-9.https://doi.org/10.1067/mob.2001.115867

9. Bashiardes S, Tuganbaev T, Federici S, Elinav E. The microbiome in anti-cancer therapy. Semin Immunol 2017; 32:74-81.https://doi.org/10.1016/j.smim.2017.04.001

10. Gopalakrishnan V, Helmink BA, Spencer CN, Reuben A, Wargo JA. The Influence of the Gut Microbiome on Cancer, Immunity, and Cancer Immunotherapy. Cancer Cell 2018; 33:570-580.https://doi.org/10.1016/j.ccell.2018.03.015

11. Sgibnev AV, Kremleva EA. Vaginal protection by $\mathrm{H}_{2} \mathrm{O}_{2^{-}}$ producing Lactobacilli. Jundishapur J Microb 2015; 8. https://doi.org/10.5812/jjm.22913

12. Dimitonova SP, Danova ST, Serkedjieva JP, Bakalov BV. Antimicrobial activity and protective properties of vaginal lactobacilli from healthy Bulgarian women. Anaerobe 2007; 13:178-84.https://doi.org/10.1016/j.anaerobe.2007.08.003

13. Ouyang QQ, Hu Z, Lin ZP, Quan WY, Deng YF, Li SD, Li $\mathrm{PW}$, Chen Y. Chitosan hydrogel in combination with marine peptides from tilapia for burns healing. Int J Biol Macr 2018; 112:1191-1198.https://doi.org/10.1016/j.ijbiomac.2018.01.217

14. Frade ML, de Annunzio SR, Calixto GMF, Victorelli FD, Chorilli M, Fontana CR. Assessment of chitosan-based hydrogel and photodynamic inactivation against propionibacterium acnes. Molecules 2018; 23(2):E473. https://doi.org/10.3390/molecules23020473

15. Figueroa-Pizano MD, Vélaz I, Peñas FJ, Zavala-Rivera P, Rosas-Durazo AJ, Maldonado-Arce AD, Martínez-Barbosa ME. Effect of freeze-thawing conditions for preparation of chitosan-poly (vinyl alcohol) hydrogels and drug release studies. Carbohydr Polym 2018; 195:476-485. https://doi.org/10.1016/j.carbpol.2018.05.004

16. Baloglu E, Karavana SY, Senyigit ZA, Guneri T. Rheological and mechanical properties of poloxamer mixtures as a mucoadhesive gel base. Pharm Dev Tech 2011; 16(6):627-636.https://doi.org/10.3109/10837450.2010.508074

17. Alavi T, Rezvanian M, Ahmad N, Mohamad N, Ng SF. Pluronic-F127 composite film loaded with erythromycin for wound application: formulation, physicomechanical and in vitro evaluations. Drug Deliv Transl Res 2017; doi: 10.1007/s13346-017-0450-z.

https://doi.org/10.1007/s13346-017-0450-z

18. Stoyancheva G, Marzotto M, Dellaglio F, Torriani S. Bacteriocin production and gene sequencing analysis from vaginal Lactobacillus strains. Arch Microbiol 2014; 196:645-653.https://doi.org/10.1007/s00248-014-0384-7

19. Malli S, Bories C, Pradines B, Loiseau PM, Ponchel G, Bouchemal K. In situ forming pluronic $®$ F127/chitosan hydrogel limits metronidazole transmucosal absorption. European J Pharm Biopharm 2017; 112:143-147. https://doi.org/10.1016/j.ejpb.2016.11.024

20. Benli M, Yiğit N. Ülkemizde yaygın kullanımı olan kekik (Thymus vulgaris) bitkisinin antimikrobiyal aktivitesi. Orlab On-Line Mikrobiyoloji Dergisi 2005; 3:1-8.

21. Boonlai W, Tantishaiyakul V, Hirun N, Sangfai $T$, Suknuntha K. Thermo sensitive Poloxamer 407/Poly (Acrylic Acid) Hydrogels with potential application as injectable drug delivery system. AAPS Phar Sci Tech 2018; 19(5):2103-2117.https://doi.org/10.1208/s12249-018-1010-7

22. Wang W, Hui PCL, Wat E, Ng FSF, Kan CW, Wang X, Wong ECW, Hu H, Chan B, Lau CBS, Leung PC. In vitro drug release and percutaneous behavior of poloxamer-based hydrogel formulation containing traditional Chinese medicine. Colloids Surf B Bioint 2016; 148:526-532. https://doi.org/10.1016/j.colsurfb.2016.09.036 